\title{
The impacts of deglacial meltwater forcing on the South Atlantic Ocean deep circulation since the Last Glacial Maximum
}

\author{
J. M. Marson ${ }^{1}$, I. Wainer ${ }^{1}$, M. M. Mata ${ }^{2}$, and Z. Liu $^{3}$ \\ ${ }^{1}$ Instituto Oceanográfico, Universidade de São Paulo, São Paulo, SP, Brazil \\ ${ }^{2}$ Instituto de Oceanografia, Universidade Federal de Rio Grande (FURG), Rio Grande, RS, Brazil \\ ${ }^{3}$ Center for Climatic Research and Department of Atmospheric and Oceanic Sciences, University of Wisconsin, \\ Madison, Wisconsin, USA \\ Correspondence to: J. M. Marson (jmarson@usp.br)
}

Received: 29 October 2013 - Published in Clim. Past Discuss.: 22 November 2013

Revised: 7 August 2014 - Accepted: 11 August 2014 - Published: 17 September 2014

\begin{abstract}
A NCAR-CCSM3 (National Center for Atmospheric Research - Community Climate System Model version 3) state-of-the-art transient paleoclimate simulation with prescribed freshwater inflows is used to investigate the changes and evolution of the South Atlantic water mass structure from the Last Glacial Maximum (LGM) to the present day. Model results show that $21000 \mathrm{yr}$ ago the water column was substantially stratified due to the presence of a saltier-than-today Antarctic Bottom Water (AABW), forming a salinity barrier that prevented dense waters from the Northern Hemisphere from sinking. This salinity barrier started to erode after the termination of the Heinrich event 1 , when its associated meltwater was transported southward, freshening the AABW. The removal of the barrier after 14 ka triggered the production of the North Atlantic Deep Water (NADW), which spread into the deeper layers of the South Atlantic at the onset of the Holocene. At this point, the NADW acquired its modern-day structure, establishing a deeper Atlantic meridional overturning circulation (AMOC).
\end{abstract}

\section{Introduction}

Twenty-one thousand years ago, the earth was experiencing its Last Glacial Maximum (LGM). The mean global temperature was almost $6^{\circ} \mathrm{C}$ lower than at pre-industrial times (Schneider von Deimling et al., 2006), which was further reinforced by lower atmospheric $\mathrm{CO}_{2}$ concentrations (Monnin et al., 2001). These conditions led to increased sea ice formation (Liu et al., 2005) and extensive associated brine in- jection into the Southern Ocean (Shin et al., 2003). A salty (and therefore denser) version of the Antarctic Bottom Water (AABW) was present then (Adkins et al., 2002; Marchitto et al., 2002; Curry and Oppo, 2005), which acted as a subsurface salinity barrier, i.e., a strong vertical stratification that prevented other water masses from entering the AABW domain. Adkins (2013) points out that the LGM ocean had a much lower vertical mixing rate than the modern one. According to chemical proxy evidence, AABW filled most of the Atlantic Ocean basin at the LGM, while the North Atlantic produced a water mass that penetrated only to the mid-depths of the Atlantic (Duplessy et al., 1988; Boyle and Leach, 1995; Yu et al., 1996; Curry and Oppo, 2005; Lynch-Stieglitz et al., 2006; Marchitto and Broecker, 2006). This water mass was much shallower than the modern North Atlantic Deep Water (NADW) and can be referred as the Glacial North Atlantic Intermediate Water - GNAIW (e.g., Duplessy et al., 1988). As a consequence of this water mass configuration, the Atlantic meridional overturning circulation (AMOC) upper limb was shallower at $21 \mathrm{ka}$ (ka: thousands of years ago) than today (Lippold et al., 2012; Zhang et al., 2013).

The increasing summer insolation in the Northern Hemisphere $(\mathrm{NH})$ since $21 \mathrm{ka}$ is considered the trigger of the last deglaciation. The early deglaciation meltwater from the North Atlantic (He et al., 2013) and the Southern Hemisphere insolation forcing (Stott et al., 2007; Huybers and Denton, 2008; Timmermann et al., 2009) may have also played active roles in raising $\mathrm{CO}_{2}$ levels, which further amplified an all-season global temperature increase. From this point on, 
the ice sheets began to retract, releasing a large amount of freshwater into the ocean.

The first major source of freshwater into the North Atlantic was a massive iceberg surge known as Heinrich event 1 (H1), which took place between 19 and $14.6 \mathrm{ka}$ (Stanford et al., 2011). When the meltwater release stopped, there was an abrupt warming event called Bølling-Allerød (BA). Then, at approximately $14 \mathrm{ka}$, the meltwater pulse $1 \mathrm{~A}$ (MWP-1A) took place - a significant freshwater discharge seen in sea level records as a $20 \mathrm{~m}$ rise (Fairbanks, 1989). The origins of MWP-1A have been discussed in the last decades and are still the subject of controversial debate. It has been suggested by several authors that this freshwater input came solely from the Laurentide Ice Sheet (LIS) over North America, ruling out any contribution from the Southern Hemisphere (SH) (Fairbanks, 1989; Peltier, 1994, 2005; Peltier and Fairbanks, 2006; Bentley et al., 2010; Mackintosh et al., 2011; Anderson et al., 2013). On the other hand, several studies support the idea of a significant freshwater contribution from the Antarctic ice sheet (AIS) (Clark et al., 1996, 2002; Kienast et al., 2003; Weaver et al., 2003; McManus et al., 2004; Bassett et al., 2005, 2007; Carlson, 2009; Stenni et al., 2010; Bethke et al., 2012; Carlson et al., 2012; Deschamps et al., 2012; Gregoire et al., 2012). During the Younger Dryas (YD, between 12.9 and $11 \mathrm{ka}$ ), a Heinrich-like event (H0) also occurred (e.g., Andrews et al., 1995), contributing to a new freshwater input into the North Atlantic. The YD period was followed by the Holocene, when the remaining parts of the LIS disappeared (e.g., Carlson et al., 2007).

It is believed that freshwater inflow into the Atlantic Ocean played a significant role in past climate changes. Menviel et al. (2011), using an earth system model of intermediate complexity forced by continuously varying boundary conditions and a hypothetical profile of freshwater forcing, were able to simulate H1, the BA warm period, the Older Dryas, the Antarctic Cold Reversal (ACR) and the YD in close agreement with paleo-proxy data. The freshwater flux and freshwater transport play an important role in inhibiting heat release from the ocean and in determining dense water sinking regions. The influence of salinity became important since it is the key element that causes the nonlinear instability of the thermohaline system (Stommel, 1961). The freshwater inflow has a stabilizing effect on the water column which changes (weakens) fundamentally the formation of the dense water masses, the main drivers of the thermohaline circulation (e.g. Broeker, 1998, Ganopolski and Rahmstorf, 2001). The link between freshwater and climate, thus, is primarily given by the restructuring of the AMOC (e.g., Broeker, 1990; Mikolajewicz, 1998; Seidov et al., 2001).

The chief players of the lower and upper limbs of the modern AMOC are two dense water masses - the Antarctic Bottom Water (AABW) and the North Atlantic Deep Water (NADW), respectively. Seidov et al. (2001) and Weaver et al. (2003) suggested that meltwater discharges near the location of dense water formation in one hemisphere may lead to the strengthening of the ocean circulation in the other hemisphere. In other words, when freshwater enters the North Atlantic, for example, the NADW formation rate decreases, which allows more formation of AABW in the south. The NADW is then displaced upward in the water column, leading to a shallower AMOC upper limb. This idea of a varying meridional overturning circulation between hemispheres feeding the deep, dense currents that drive the overturning circulation is not new. The key point is that the strength of the circulation is out of phase with respect to the North and South hemispheres.

There are numerous meltwater modeling studies that discuss the North Atlantic dense water (generically called NADW) formation decrease in response to freshwater input. Rind et al. (2001), in a study with the Goddard Institute for Space Studies (GISS) model, discuss the impact of freshwater inflow relative to the weakening of the NADW either from glacial melting (e.g., Broecker et al., 1985) or from ice sheet instabilities. Their results show a rather linear response of the NADW decrease relative to the amount of input of freshwater. Rind et al. (2001) also point out that other studies discuss changes in the NADW associated with the millennial-scale cooling events (Charles et al., 1996; Manabe and Stouffer, 1997; Zahn et al., 1997; Curry et al., 1999). Proxy records of ${ }^{231} \mathrm{~Pa} /{ }^{230} \mathrm{Th}$ ratios recorded in a Bermuda Rise sediment core (Stanford et al., 2006), for example, suggest a weak AMOC at H1 (McManus et al., 2004), which resulted from a decreased NADW production. The same happened in the Younger Dryas, after which there is evidence of the strengthening of the NADW (Jouzel et al., 1995; Hughen et al., 1998; Weaver et al., 2003).

In this study, the above aspects of Atlantic Ocean deep circulation are assessed using the results of a transient simulation of the last 22000 years, which is forced by several meltwater pulses identified by changes in the sea level records. This simulation is an extension of the DGL-A experiment described in Liu et al. (2009). In their study, Liu et al. investigated the trigger for the Bølling-Allerød warming. He et al. (2013) also used the DGL-A simulation to determine the importance of each forcing - orbital, greenhouse gas concentrations, ice sheet configuration - to the temperature evolution from the LGM to BA in Greenland and Antarctica. The simulation examined here extends to the present day, with the focus on the South Atlantic deep ocean.

We hypothesize that the present-day circulation pattern of the South Atlantic Ocean was established approximately at the onset of the Holocene (11 ka). Therefore, we investigate the impacts of the deglacial freshwater discharge, assuming contributions from both hemispheres, on the structure of the deep circulation in South Atlantic Ocean. We show that the spreading of the NADW to the South Atlantic was possible after the deglacial freshening of AABW eroded the subsurface salinity barrier present at the LGM. The ocean model results are examined with respect to the AMOC, meridional 
heat and freshwater transport time series, and the salinity distribution for the South Atlantic basin.

\section{Data and methods}

The results of a paleoclimate transient simulation using the Community Climate System Model version 3 (CCSM3) are used in this study. The simulation experiment analyzed is referred to as TraCE-21K. It was run from $22 \mathrm{ka}$ to $0 \mathrm{ka}(\mathrm{He}$, 2011) as an extended version of the DGL-A experiment discussed in Liu et al. (2009).

CCSM is a global coupled model developed by the National Center for Atmospheric Research (NCAR). It is composed of four components: atmosphere, ocean, land surface and sea ice (Boville and Gent, 1998). The atmospheric component of this model is the Community Atmospheric Model (CAM) version 3 with a $\sim 3.75^{\circ}$ in horizontal resolution and 26 hybrid coordinate levels in the vertical (Collins et al., 2006). The ocean component of this model is the Parallel Ocean Program (POP), a three-dimensional primitive equation model in vertical z-coordinate (Gent et al., 2006). The ocean grid has a dislocated north pole over Greenland, and 25 levels extending to $5.5 \mathrm{~km}$ depth. Its horizontal resolution is approximately $3.6^{\circ}$ in longitude and is variable along latitudes, with greater resolution in the tropics and North Atlantic. The sea ice model is a dynamic-thermodynamic formulation, which includes a sub-grid-scale ice thickness distribution and elastic-viscous-plastic rheology (Briegleb et al., 2004). The sea ice model uses the same horizontal grid and land mask as the ocean model.

The TraCE-21K run was initialized using the results of the CCSM3 LGM simulation described by Otto-Bliesner et al. (2006). This simulation has concentrations of atmospheric greenhouse gases based on ice core measurements (Flückiger et al., 1999; Dällenbach et al., 2000; Indermühle et al., 2000) and are given in Otto-Bliesner et al. (2006, their Table 1) as are the atmospheric aerosols. The concentrations of atmospheric carbon dioxide $\left(\mathrm{CO}_{2}\right)$, methane $\left(\mathrm{CH}_{4}\right)$ and nitrous oxide $\left(\mathrm{N}_{2} \mathrm{O}\right)$ are decreased relative to the pre-industrial values, resulting in a total decrease in radiative forcing of the troposphere of $2.76 \mathrm{Wm}^{-2}$. The majority of this change $\left(2.22 \mathrm{Wm}^{-2}\right)$ results from a decrease in the amount of $\mathrm{CO}_{2}$. Continental ice sheet extent and topography in the LGM CCSM3 simulation are from the ICE-5G reconstruction (Peltier, 2004). The coastline is also taken from the ICE-5G reconstruction and corresponds to a sea level lowering of $\sim 120 \mathrm{~m}$. The orbital parameters at $21 \mathrm{ka}$ (Berger, 1978) are used to determine the total solar flux. The LGM ocean is initialized by applying anomalies of the ocean threedimensional potential temperature and salinity fields derived from a LGM run with the Climate System Model version 1.4 (CSM1.4, Shin et al., 2003). This approach allows a shorter spin-up phase by starting with a previous LGM simulation that reached quasi-equilibrium.
This LGM condition was run coupled to a vegetation module for 1800 years before initializing the TraCE-21K simulation. The initial fields present a colder and saltier deep ocean compared to the present-day thermohaline structure, which is in agreement with previous studies (Adkins, 2013). The North Atlantic, in particular, presents a very dense vertical profile in the subsurface and deep ocean, giving the LGM ocean its highly stratified characteristic. For the prescribed forcing fields, TraCE-21K adopted transient orbital parameters and transient concentrations of greenhouse gases $\left(\mathrm{CO}_{2}\right.$, $\mathrm{CH}_{4}$ and $\mathrm{N}_{2} \mathrm{O}$ ) from Joos and Spahni (2008). The coastlines and ice sheets volume changed every 500 years according to ICE-5G reconstruction (Peltier, 2004), which also reflects the sea level variability.

The meltwater discharges were added to the ocean model as a freshwater flux to the ocean surface (He, 2011). The unit of freshwater flux was obtained by dividing the corresponding sea level rise by the total area where freshwater was inserted. The meltwater scheme (summarized in Fig. 1a) and their locations (shown in Fig. 1b) for this simulation are described in Liu et al. (2009) and He (2011) as follows. From $19 \mathrm{ka}$ to $18.4 \mathrm{ka}$, the first meltwater pulse was imposed at the rate of $3 \mathrm{~m} \mathrm{kyr}^{-1}\left(1 \mathrm{~m} \mathrm{kyr}^{-1}=0.0115 \mathrm{~Sv} ; 1 \mathrm{~m} \mathrm{kyr}^{-1}\right.$ refers to $1 \mathrm{~m}$ of equivalent global sea level rise per 1000 years) over the North Atlantic. From $18.4 \mathrm{ka}$ to $17.5 \mathrm{ka}$, this freshwater input was increased linearly from 0 to $5 \mathrm{~m} \mathrm{kyr}^{-1}$ in the Gulf of Mexico and from 3 to $5 \mathrm{~m} \mathrm{kyr}^{-1}$ in the North Atlantic. From $17.5 \mathrm{ka}$ to $17.0 \mathrm{ka}$, the meltwater inflow remained at $5 \mathrm{~m} \mathrm{kyr}^{-1}$ in the Gulf of Mexico and linearly increased from 5 to $15 \mathrm{~m} \mathrm{kyr}^{-1}$ in the North Atlantic. Starting in $17 \mathrm{ka}$, the meltwater flux in the Gulf of Mexico was shut off immediately after $17.0 \mathrm{ka}$, while the meltwater flux in the North Atlantic remained at $15 \mathrm{~m} \mathrm{kyr}^{-1}$ until $14.67 \mathrm{ka}$ when it was abruptly shut off. The meltwater discharge applied to simulate MWP-1A was a $500 \mathrm{yr}$ meltwater pulse in both hemispheres, with the rate of meltwater discharge in the Southern Hemisphere 3 times that in the Northern Hemisphere; thus, $5 \mathrm{~m}$ (Carlson, 2009) of sea level rise came from the north and $15 \mathrm{~m}$ from the south. From $13.8 \mathrm{ka}$ to $13.1 \mathrm{ka}$, the meltwater flux is $10 \mathrm{~m} \mathrm{kyr}^{-1}$. From 12.9 to 11.3 , it is $20 \mathrm{~m} \mathrm{kyr}^{-1}$. For the Holocene, there is a constant freshwater inflow from $9 \mathrm{ka}$ to $8 \mathrm{ka}$ of $10 \mathrm{~m} \mathrm{kyr}^{-1}$, and half of that from about $8.5 \mathrm{kyr}$ to $6.9 \mathrm{kyr}$. The values chosen were estimates of sea level rise from data records presented in Clark et al. (2002) and Peltier (2004). Geological indicators of ice sheet retreat and meltwater discharge were obtained from Licciardi et al. (1999), Clark et al. (2001, 2002), Clark and Mix (2002), Carlson (2009).

The meridional heat transport through a section of the Atlantic basin was calculated as in Bryan (1962):

$$
Q_{t}=\int_{5000 \mathrm{~m}}^{0} \cdot \int_{70 \mathrm{~W}}^{20 \mathrm{~W}} c_{p} \rho \theta v \mathrm{~d} x \mathrm{~d} z
$$



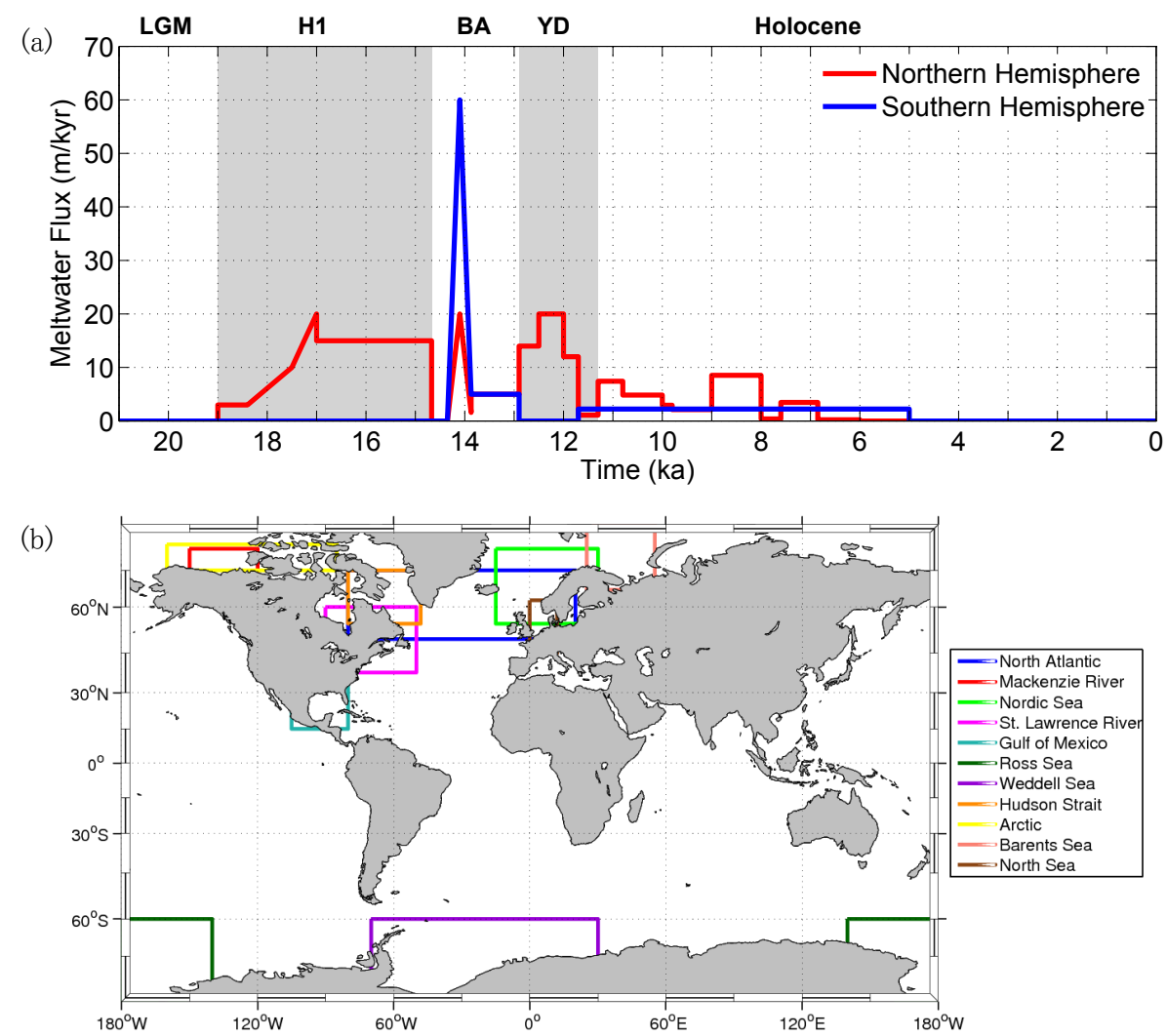

Figure 1. Meltwater discharges from the Northern (red line) and Southern (blue line) hemispheres (a) $\left(1 \mathrm{~m} \mathrm{kyr}^{-1}=1 \mathrm{~m}\right.$ of equivalent global sea level rise per 1000 years $=0.0115 \mathrm{~Sv})(\mathrm{He}, 2011)$. The main climatic events in the last deglaciation are also marked: Last Glacial Maximum (LGM), Heinrich event 1 (H1), Bølling-Allerød (BA), Younger Dryas (YD) and Holocene. Locations where the meltwater was injected into the TraCE-21K simulation (b) (adapted from He, 2011).

where $Q_{t}$ is the meridional heat transport, $c_{p}$ is the sensible heat of seawater, $\rho$ is seawater density, $v$ is the meridional velocity and $\theta$ is the potential temperature. The meridional salt transport was calculated in the same way, simply substituting $c_{p} \theta$ by $S$, where $S$ is the salinity of seawater.

Here, we use the salinity as a tracer of the predominant water masses and their spatial distribution. In particular, the NADW is defined as being a tongue-like signal of maximum salinity around $2500 \mathrm{~m}$ depth in vertical profiles across all longitudes spanning the Atlantic basin extending from the northern high latitudes into the Southern Ocean. The thermohaline signature of NADW was analyzed for the South Atlantic $\left(0-30^{\circ} \mathrm{S}\right)$, where this water mass is well defined.

\section{Results and discussion}

In contrast to the Pacific Ocean, where the heat is transported from the equator to the poles, the meridional heat transport in the South Atlantic is directed northward. This happens because the upper branch of the AMOC carries warm surface layer waters northward to compensate for the great amount of heat loss in the Nordic seas. Therefore, studying the South
Atlantic circulation is instrumental to fully understand the earth's climate system.

The northern ocean heat transport (NOHT) for the South Atlantic $\left(0-30^{\circ} \mathrm{S}\right)$ is shown in Fig. 2a (purple curve). Apart from the cold LGM period, positive values - which indicate northward transport - coincide with warm periods in the Northern Hemisphere. A sharp increase of the NOHT at $\sim 14.7 \mathrm{ka}$ (which coincides with the Bølling-Allerød (BA) warming in the north) is evident. The heat transport is higher at LGM than at modern times, which is consistent with the hypothesis that the AMOC was stronger at $21 \mathrm{ka}$ as discussed by Shin et al. (2003) and Clauzet et al. (2007).

Near-zero and negative meridional heat transport are associated with the Northern Hemisphere cooling relative to the H1 and Younger Dryas (YD) events, while temperature increases in the Southern Hemisphere. After $11 \mathrm{ka}$, the heat transport values show a steady, small rise to about 0.25 $0.3 \mathrm{PW}$ until about $6 \mathrm{ka}$ after which it remains practically constant at that level, indicating a stable equilibrium at the same time that the meltwater pulses are shutdown in the simulation.

The NOHT as a function of latitude averaged for each of the key climatic periods in the simulation is shown in 

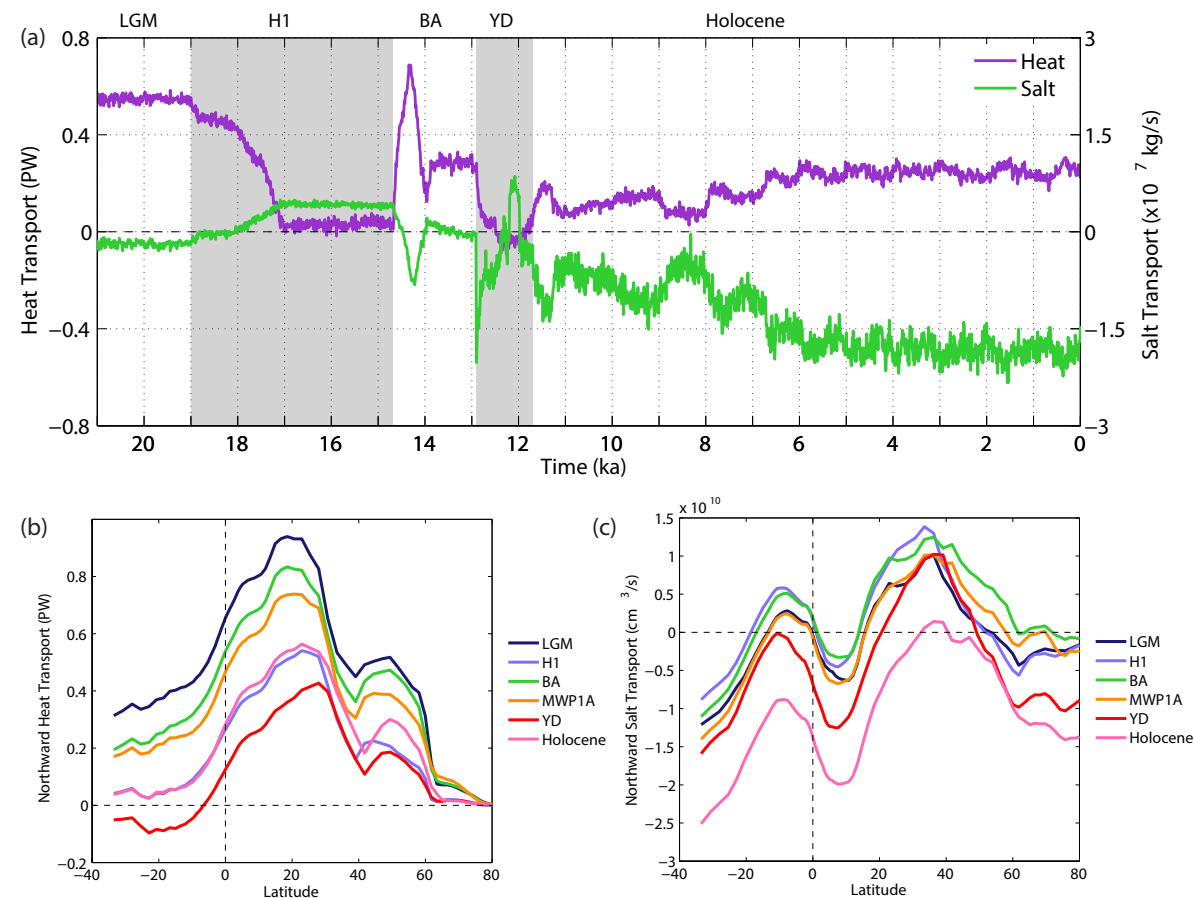

Figure 2. TraCE-21K meridional heat (purple) and salt (green) transport between $30^{\circ} \mathrm{S}$ and $0^{\circ}$ (a). Positive values denote northward transport. The main climatic events in the last deglaciation are also marked: Last Glacial Maximum (LGM), Heinrich event 1 (H1), BøllingAllerød (BA), Younger Dryas (YD) and Holocene. Northward transport of heat (PW) (b) and northward transport of salt $\left(\mathrm{cm}^{3} \mathrm{~s}^{-1}\right)(\mathbf{c})$, averaged for each key period when freshwater was injected into the ocean.

Fig. 2b. NOHT has a maximum in the North Atlantic in the tropics, centered at $20^{\circ} \mathrm{N}$ for the LGM and BA. This maximum shifts a few degrees north for the MWP-1A period. For the YD and Holocene, the maximum northward transport is at about $25^{\circ} \mathrm{S}$ and $30^{\circ} \mathrm{S}$, respectively. The changes in magnitude of the NOHT between the periods are related to air-sea interaction in the tropics as discussed by Cheng et al. (2007). They discuss the AMOC slowdown, the related NOHT and the mechanisms for the high-latitude tropical coupling through freshwater perturbation experiments. In the South Atlantic, with exception of the YD, the transport is northward, largest at LGM, decreasing nonlinearly at BA and MWP-1A and very small for $\mathrm{H} 1$ and the Holocene. The northward ocean salt transport (NOST) as a function of latitude is shown in Fig. 2c. The NOST between the key climatic periods shows its maximum values between $30-40^{\circ} \mathrm{N}$ with a secondary maximum at $10^{\circ} \mathrm{S}$. In the North Atlantic, the ocean salt transport is southward for all periods (except the Holocene) from the Equator to about $20^{\circ} \mathrm{N}$, after which it becomes poleward until $60^{\circ} \mathrm{N}$, when it reverts to southward. The strongest NOST is during H1, followed by BA, LGM and YD. During the Holocene with the exception of a small, albeit positive, NOST at about $38^{\circ} \mathrm{N}$, all the salt transport is southward. In the South Atlantic, there is northward salt transport at H1, BA and LGM, which is reversed southward at $\mathrm{YD}$ and Holocene.

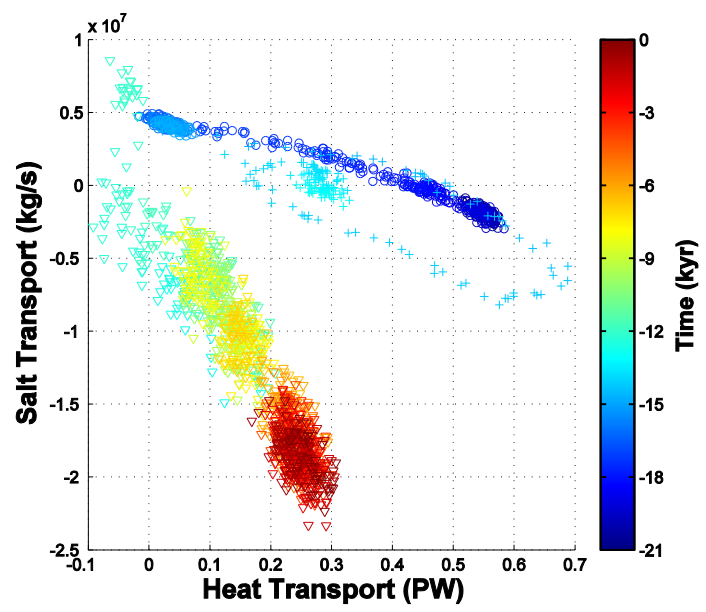

Figure 3. Scatter diagram showing negative correlation between heat and salt transport in South Atlantic $\left(30-0^{\circ} \mathrm{S}\right)$. The circles represent data for the period that precede the Bølling-Allerød event; the crosses stand for the BA period; and the triangles show data from Younger Dryas on. The colors stand for time evolution, according to the color bar on the right.

The relationship between the TraCE-21K meridional heat transport and the meridional salt transport (Fig. 2a, green curve) shows an out-of-phase behavior between the two time series. This is best illustrated by the scatter diagram in Fig. 3 . 


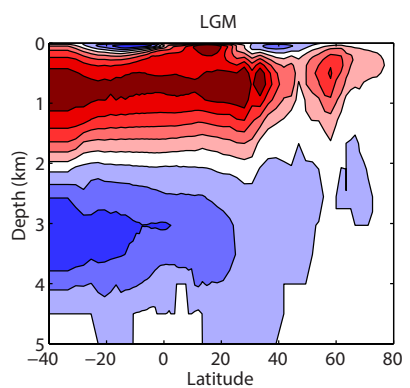

d)

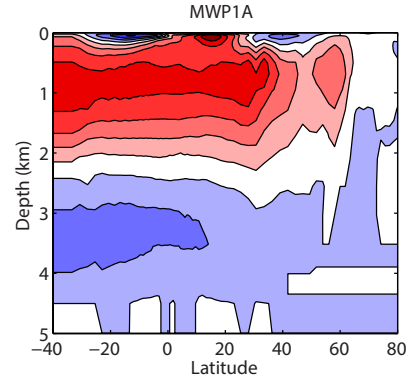

b)

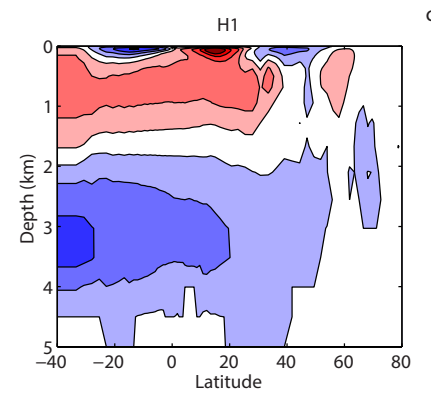

e)

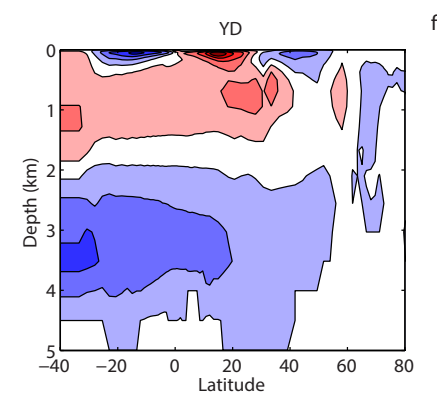

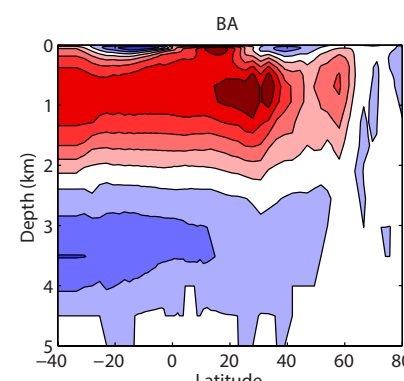

f)

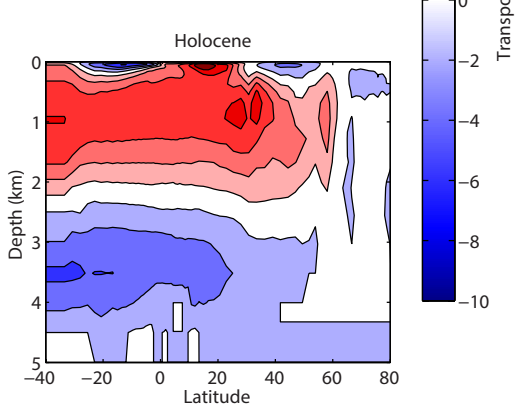

Figure 4. Overturning function averaged for each period: (a) LGM (22 ka-19ka); (b) H1 (19 ka-14.67 ka); (c) BA (14.67 ka-14.35 ka); (d) MWP-1A (14.35 ka-13.85 ka); (e) YD (12.9 ka-11.3 ka); (f) Holocene (11.3 ka-0 ka). The colors represent transport, in Sverdrup.

It shows that the negative correlations between heat and salt transport are high before and after the BA warming period (circles with a correlation coefficient $(r)$ of -0.99 , and triangles with $r=-0.93$, respectively). During the transition from approximately $14.7 \mathrm{ka}$ to $12.9 \mathrm{ka}$, the correlation diminishes (but is still significant; Fig. 3, crosses with $r=-0.79$ ) due to the reorganization of the deep ocean structure. The different slopes of the circle and triangle clusters in Fig. 3 indicate that, overall, the transport exhibits two regimes: a large heat and small salt transport before BA and a small heat and large salt transport especially after YD (greenish to reddish tones).

If we consider the salt transport via water masses, the AABW fills the Atlantic basin from LGM to BA due to the limited extension of GNAIW. After that, the developing NADW starts transporting salt southward, and at the same time there is more heat being transported to the north (as in Seidov and Maslin, 2001). The same is true for AABW at the beginning of the simulation (more glacial AABW means export of salt northward and more heat southward). The increase or decrease in NOHT and NOST is related to the location of the prescribed freshwater fluxes. For example, the MWP-1A that discharged the equivalent of $15 \mathrm{~m} \mathrm{kyr}^{-1}$ of freshwater into the Southern Ocean, where the AABW is formed, would cause its North Atlantic counterpart to transport salt southward more intensely. According to Seidov and Maslin (2001), for example, a stronger NADW is associated with increased northward heat transport, more salt transported to the south, leading to an inverse correlation.
The meridional overturning function (AMOC) at the LGM for the TraCE-21K results is intensified (Fig. 4a). The upper branch of the overturning is homogeneously strong in both hemispheres while the lower branch shows a vigorous Southern Hemisphere circulation, associated with the intensified AABW formation, occupying most of the deep Atlantic basin. During H1 (Fig. 4b), the intensified lower limb is still present with the maximum transport of 8-10 Sv confined south of $25^{\circ} \mathrm{S}$. The upper limb changes significantly, becoming consistently weaker in both hemispheres. The maximum transport $(\sim 10 \mathrm{~Sv})$ at about $1000 \mathrm{~m}$ at the LGM is significantly reduced in H1 (max $\sim 4 \mathrm{~Sv}$ ). During BA (Fig. 4c) and MPW-1A (Fig. 4d), the deeper circulation of the lower limb weakens while the upper limb intensifies. In the BA, there is an intensification of about $4-6 \mathrm{~Sv}$ centered at $1000 \mathrm{~m}$ between $20-40^{\circ} \mathrm{N}$ that is not seen in Fig. 4d. The Antarctic Bottom Water picks up again during YD, which is responsible for the re-intensification of the lower limb of the meridional overturning (Fig. 4e), while the upper branch is weakened - except in the upper few hundred meters centered at $20^{\circ} \mathrm{N}$. The configuration of the meridional overturning for the Holocene is shown in Fig. 4f.

The mean potential temperature $(\theta)$ versus salinity $(S)$ for the TraCE-21K model results is shown in Fig. 5a averaged between $30^{\circ} \mathrm{S}$ and $0^{\circ}$ from the LGM (blue dots) to $0 \mathrm{ka}$ (red dots). It can be observed that there is a shift of the curve towards lower salinities throughout the entire water column, which is expected given all the freshwater entering the Atlantic Ocean in the last $21000 \mathrm{yr}$. The changes in the shape of the $\theta-S$ curve for the different periods are significant: the 

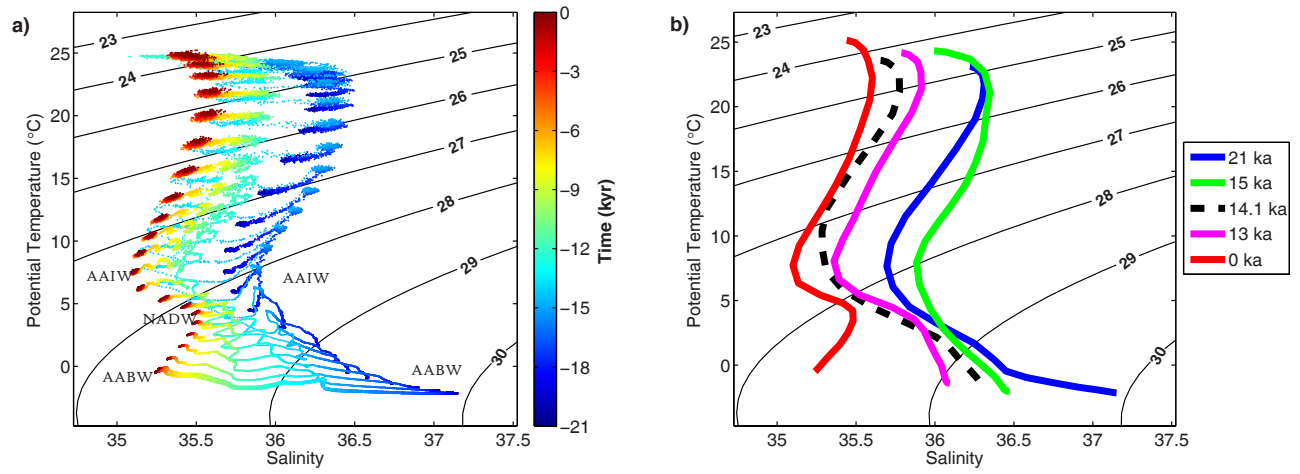

Figure 5. TraCE-21K $\theta-\mathrm{S}$ diagram averaged between $30^{\circ} \mathrm{S}$ to $0^{\circ}$, at $25^{\circ} \mathrm{W}$. Time evolution is represented by the color range (a). The acronyms indicate the main water masses: AAIW - Antarctic Intermediate Water; AABW - Antarctic Bottom Water; NADW - North Atlantic Deep Water. The $\theta-S$ diagram for the key climatic periods considered in this study: LGM (21 ka), before (15 ka), during (14.1 ka), after (13 ka) MWP-1A and $0 \mathrm{ka}(\mathbf{b})$.

$\theta-S$ curve at 21 ka has only two deep water masses, while the modern curve $(0 \mathrm{ka})$ presents the three main Atlantic Ocean deep water masses (AAIW, NADW and AABW, as in Fig. 5a). The water type that specifies the NADW characteristics (salinity maximum at $\sim 2500 \mathrm{~m}$ ) does not appear until the early Holocene.

The absence of the NADW during the glacial period is consistent with proxy records (Adkins et al., 2002). The $\theta-S$ plots considering the same latitudinal interval for the South Atlantic, averaged for $21 \mathrm{ka}, 15 \mathrm{ka}, 14.1 \mathrm{ka}, 13 \mathrm{ka}$ and $0 \mathrm{ka}$, are shown in Fig. 5b. It is clear that the deep salinity maximum characteristic of the NADW within the South Atlantic starts to develop only after $14.1 \mathrm{ka}$ (Fig. 5b, pink curve). These changes become evident when examining the vertical profiles of salinity along the Atlantic Ocean for the different climatic periods averaged for the LGM (22-19 ka), H1 (19$14.67 \mathrm{ka}), \mathrm{BA}(14.67-14.35 \mathrm{ka})$, MWP-1A (14.35-13.85 ka), YD (12.9-11.3 ka) and the Holocene (11.3-0 ka) (Fig. 6).

The Atlantic Ocean at LGM (Fig. 6a) was much more stratified than today (e.g. Adkins et al., 2002; Zhang et al., 2013) with the dense (and salty) AABW occupying much of the deep basin, as discussed before. During H1 (Fig. 6b), the slow and continuous freshwater inflow into the North Atlantic reduces the GNAIW formation with a significant freshening of the upper $1000 \mathrm{~m}$ accompanied by a drop in the total ocean heat transport (e.g., Fig. 2a). In Stanford et al. (2011), they infer, from proxy data, a slowdown of northern sourced water formation from 19 to $17.5 \mathrm{ka}$. The $\mathrm{H} 1$ meltwater discharge is interrupted at $14.67 \mathrm{ka}$ when the North Atlantic circulation recovers (Fig. 6c). The deep ocean (below 500m) is fresher. The $\mathrm{H} 1$ changes in ocean circulation have been associated with atmospheric $\mathrm{CO}_{2}$ changes (Menviel et al., 2014). It is suggested that an enhanced AABW could have been responsible for $30 \%$ of the atmospheric $\mathrm{CO}_{2}$ increase.

Between 14.35 and $13.85 \mathrm{ka}$ (Fig. 6d), the freshwater source in the Southern Ocean is activated (and re-activated in the Northern Hemisphere) in the model. A freshening of most of the upper $1000 \mathrm{~m}$ in both the North and South Atlantic can be observed. Even though this event is of much shorter duration in the model, its magnitude is about 4 times greater in the Southern Ocean (maximum of $60 \mathrm{~m} \mathrm{kyr}^{-1}$ ) than the meltwater flux in the North Atlantic at $\mathrm{H} 1$ (maximum of $15 \mathrm{~m} \mathrm{kyr}^{-1}$ ). The AABW is suppressed and only recovers at the YD (Fig. 6e), when the North Atlantic receives a new iceberg discharge that slows down the AMOC. The opening of the Bering Strait at $12.9 \mathrm{ka}$ in TraCE-21K contributes to a further weakening of the AMOC through meltwater transport from the Pacific to the Nordic seas (He, 2011).

As soon as the freshwater flux from the North Atlantic is interrupted around $11.7 \mathrm{ka}$, the heat transport towards the north is re-established. The salinity barrier, which was responsible for the high stratification in the simulation initial condition, was continuously eroded and the dense water that was confined to the surface and intermediate layers (GNAIW) can finally sink and become NADW. During the Holocene (Fig. 6f), the features of the modern NADW are in place and the model results compare well (albeit with very different spatial resolution) with observed data from the World Ocean Circulation Experiment (WOCE - not shown).

Examining the differences in the vertical salinity profile between $\mathrm{H} 1$ and LGM, BA and H1, MPW-1A and BA, YD and MWP-1A and Holocene and YD (Fig. 7) helps in understanding the changes in the ocean structure between the different periods. The Atlantic basin is considerably fresher at H1 when compared to the LGM (Fig. 7a). The largest differences are in the North Atlantic in the upper $1000 \mathrm{~m}$ with maximum values in the upper $200 \mathrm{~m}$. The subtropical South Atlantic in the upper $800-900 \mathrm{~m}$ is saltier in $\mathrm{H} 1$ compared to LGM. This is because the prolonged freshening was entirely in the North Atlantic with the residual LGM saltiness remaining in the southern subtropics' upper $\sim 800-900 \mathrm{~m}$. Figure $7 \mathrm{~b}$ shows the salinity differences between $\mathrm{H} 1$ and BA when the GNAIW recovers, which is seen by the positive salinity difference in most of the North Atlantic in the 

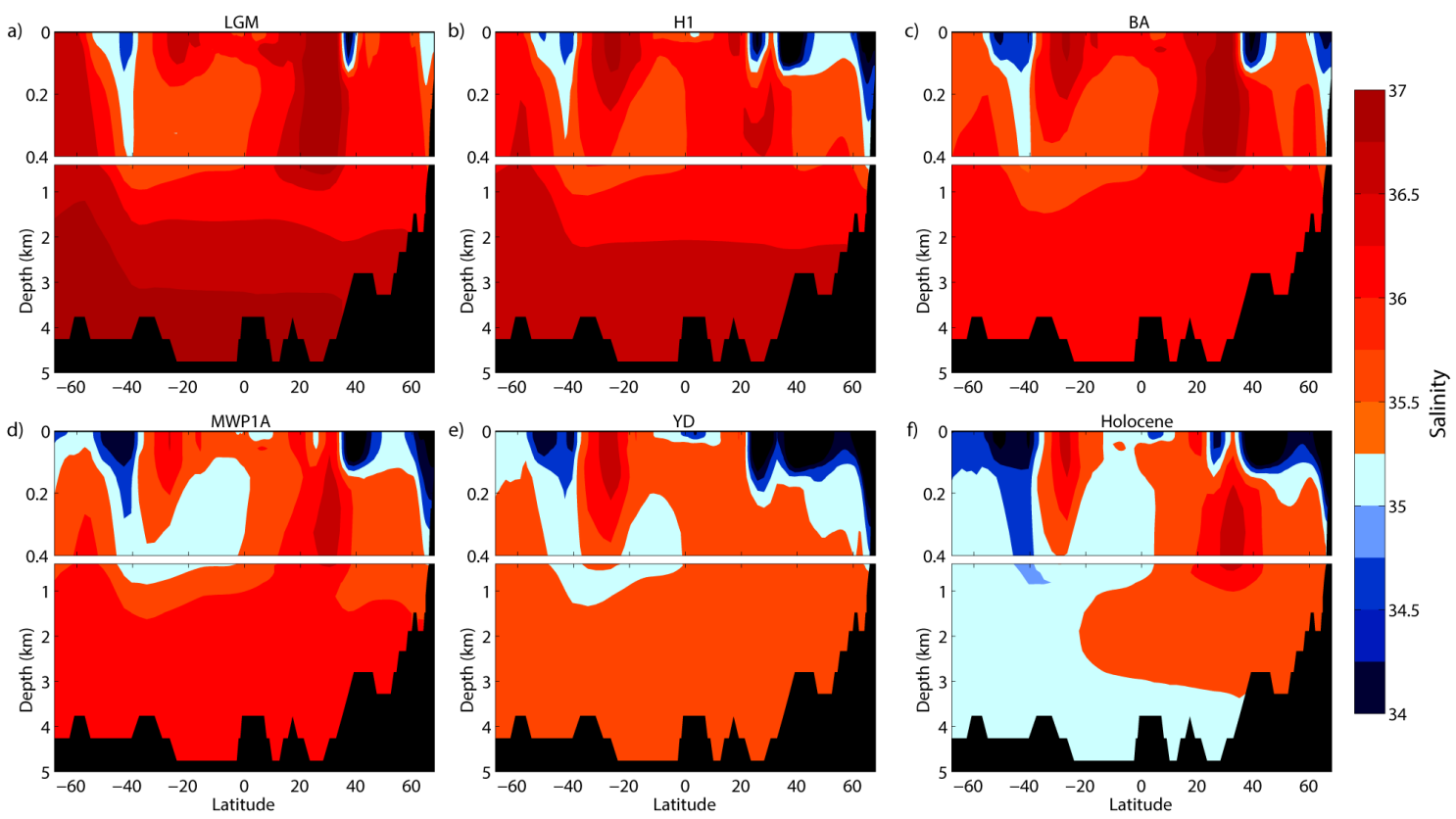

Figure 6. TraCE-21K salinity meridional sections across the Atlantic Ocean (25 W) at (a) LGM (22 ka-19 ka); (b) H1 (19 ka-14.67 ka); (c) BA (14.67 ka-14.35 ka); (d) MWP-1A (14.35 ka-13.85 ka); (e) YD (12.9 ka-11.3 ka); (f) Holocene (11.3 ka-0 ka).
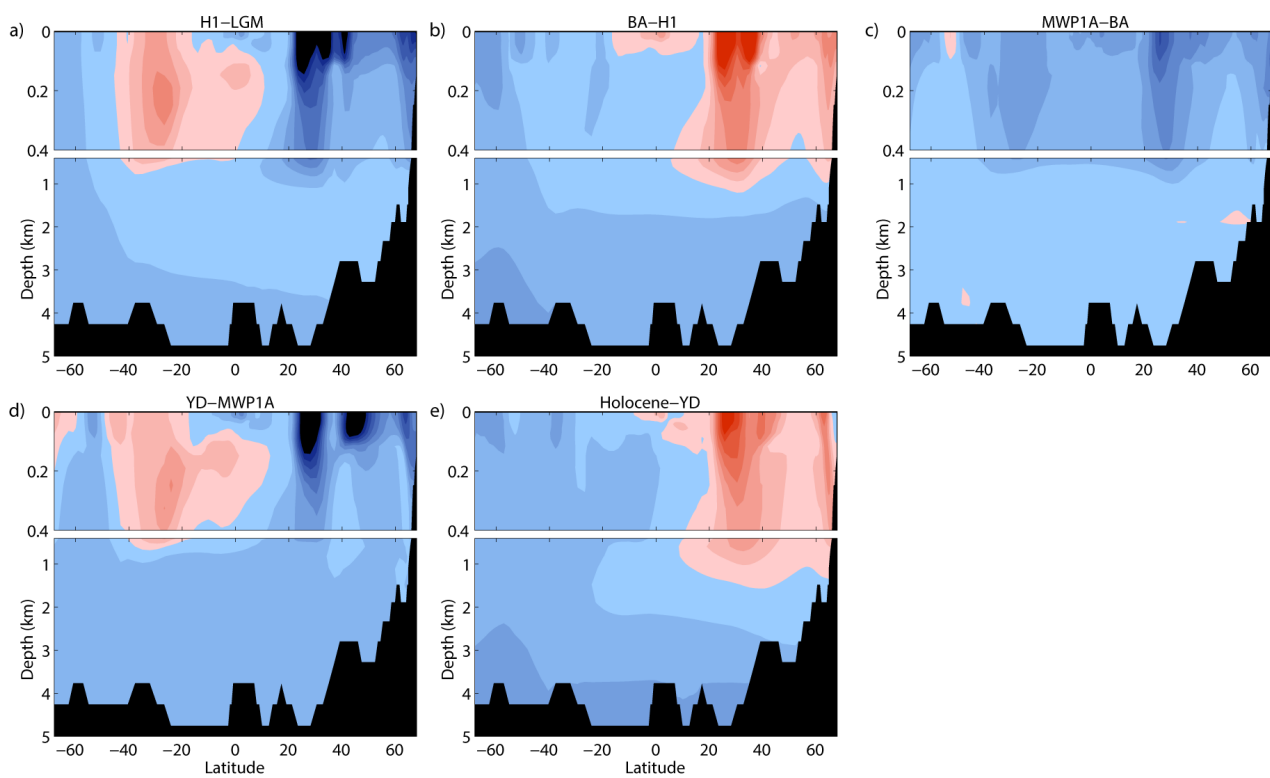

Figure 7. TraCE-21K salinity differences between (a) H1 (19ka-14.67 ka) and LGM (22 ka-19ka); (b) BA (14.67 ka-14.35 ka) and H1 (19 ka-14.67 ka); (c) MWP-1A (14.35 ka-13.85 ka) and BA (14.67 ka-14.35 ka); (d) YD (12.9 ka-11.3 ka) and MWP-1A (14.35 ka$13.85 \mathrm{ka})$; (e) Holocene (11.3 ka-0 ka) and YD (12.9 ka-11.3 ka).

upper $1000 \mathrm{~m}$, reaching the equator in the surface layers. The impact of MWP-1A with respect to BA is observed in Fig. $7 \mathrm{c}$ with a basin-wide freshening. Comparing the salinity differences between the YD event with MWP-1A (Fig. 7d) shows a similar distribution to Fig. 7a, except the deeper ocean is significantly fresher. The upper $500 \mathrm{~m}$ displays a saltier South Atlantic and a fresh North Atlantic, indicating a weaker North Atlantic dense water formation. This structure finally evolves into the opposite structure, with the newly formed NADW that is able to spread into the Southern Hemisphere as seen today.

The weaker dense water production in the $\mathrm{NH}$ during YD is discussed by several studies based on proxy data (Boyle, 1987; Hughen et al., 1998; Piotrowski et al., 2005; 
Praetorius et al., 2008; Roberts et al., 2010). Furthermore, through ${ }^{231} \mathrm{~Pa} /{ }^{230} \mathrm{Th}$ ratio analysis, Negre et al. (2010) as well as the modeling study of Wainer et al. (2012) - argue that the modern Atlantic circulation was only fully established during the Holocene, which is also consistent with the evolution of the salinity-based water mass structure presented in Fig. 6. The establishment of the NADW as the main southward component of the AMOC induced the change in the overturning circulation geometry. The AMOC became deeper, meridional heat transport became more stable and the NADW became the main salt exporter across the Atlantic Ocean. Hence, the steep triangle cluster on Fig. 3 is explained: a smaller variability of the heat transport northwards and larger salt transport southwards in the Holocene.

\section{Conclusions}

This study examined, through the analysis of the results of a transient paleoclimate numerical simulation with the NCARCCSM from the LGM to present day, the evolution of the South Atlantic Ocean deep circulation.

Our results show an initial salinity barrier placed around $1000 \mathrm{~m}$ in the LGM Atlantic Ocean. This salinity barrier is associated with the formation of a saltier version of AABW (Fig. 6a). As the upper North Atlantic gets flooded by freshwater during the $\mathrm{H} 1$ and this freshwater reaches the deep ocean through the Southern Ocean, the ocean's vertical structure starts changing but the salinity stratification still only allows the formation of an intermediate water mass in the North Atlantic, the so-called GNAIW (Figs. 5b and 6a). Further freshening occurs at MPW-1A. The impact on the ocean structure resulting from continuous freshening combined with further freshening at YD (Figs. 5d, e and 6d) allows the erosion of the salinity barrier that was preventing the spread of the NADW into the South Atlantic. The newly formed NADW is allowed to sink and spread southward (Fig. 5f). This sequence of events is coherent with the results of Menviel et al. (2011). They discuss that melting from both LIS and AIS contributed to the sea level rise associated with MWP-1A. In their work, they discuss how the different and opposite locations of the MWP-1A contribute to different processes: the Northern Hemispheric source of MWP-1A would be associated with the Older Dryas cooling in the Northern Hemisphere, whereas melting of the AIS would be associated with the ACR cooling.

During the Holocene, the vertical distribution of salinity (related to the distribution of Atlantic water masses) reaches its modern-day pattern (Fig. 5f). The present-day NADW owes its spatial structure to the impact of several freshwater discharges in the Atlantic, which contributed to the erosion of the subsurface salinity barrier formed at LGM. The erosion allowed the basin-wide distribution of the NADW, giving it its modern-day features.
We analyzed a single transient run where no control simulation or other companion sensitivity experiments were available to access uncertainties and robustness of the results with respect to each individual meltwater flux. Furthermore, there are other intrinsic uncertainty sources such as the prescribed meltwater flux in TraCE-21 (that is obtained indirectly from sea level records) plus the fact that the timing, magnitude and location of MWP-1A, associated with global sea level change, has significant uncertainty as well. Since the meltwater fluxes were prescribed, it does not necessarily mean that the model has the correct sensitivity to the freshwater input.

In this respect, interpretation of the results has to be taken with caution considering that the lack of a control run does not allow us to single out cause and effect relationships relative to individual events. Nonetheless, the transient nature of the simulation permits the formulation of a broad picture of how the deep Atlantic evolved.

Acknowledgements. This work was supported by the grants 2011/02047-9 and 2013/02111-4 from the Fundação de Amparo à Pesquisa do Estado de São Paulo (FAPESP), CAPES-Ciências do Mar and CNPq-MCT INCT-Criosfera. We also wish to thank P2C2 program/NSF, Abrupt Change Program/DOE, INCITE program/DOE, NCAR and Bette Otto-Bliesner for making the TraCE-21K available, as well as NOAA-PANGEA for the paleoclimatic proxy data. We also wish to thank the anonymous referees for their constructive reviews. The comments of Lawrence A. Mysak in the revised version of this paper are also appreciated.

Edited by: U. Mikolajewicz

\section{References}

Adkins, J. F.: The role of deep ocean circulation in setting glacial climates. Paleoceanography, 28(3), 539-561, 2013.

Adkins, J. F., McIntyre, K., and Schrag, D. P.: The salinity, temperature, and $\delta 180$ of the glacial deep ocean, Science, 298, 17691773, 2002.

Anderson, J. B., Kirshner, A. E., and Simms, A. R.: Constraints on Antarctic Ice Sheet configuration during and following the last glacial maximum and its episodic contribution to sea-level rise, Special Publications, 381, Geological Society, London, doi:10.1016/S0277-3791(01)00083-X, 2013.

Andrews, J. T., Jennings, A. E., Kerwin, M., Kirby, M., Manley, W., Miller, G. H., Bond, G., and MacLean, B.: A Heinrich-like event, H-0 (DC-0): Source (s) for detrital carbonate in the North Atlantic during the Younger Dryas Chronozone, Paleoceanography, 10, 943-952, 1995.

Bassett, S. E., Milne, G. A., Mitrovica, J. X., and Clark, P. U.: Ice sheet and solid earth influences on far-field sea-level histories, Science, 309, 925-928, 2005.

Bassett, S., Milne, G., Bentley, M., and Huybrechts, P.: Modelling Antarctic sea-level data to explore the possibility of a dominant Antarctic contribution to meltwater pulse IA, Quaternary Sci. Rev., 26, 2113-2127, 2007. 
Bentley, M. J., Fogwill, C. J., Le Brocq, A. M., Hubbard, A. L., Sugden, D. E., Dunai, T. J., and Freeman, S. P.: Deglacial history of the West Antarctic Ice Sheet in the Weddell Sea embayment: constraints on past ice volume change, Geology, 38, 411-414, 2010.

Berger, A.: Long-term variations of daily insolation and Quaternary climatic changes, J. Atmos. Sci., 35, 2362-2367, 1978.

Bethke, I., Li, C., and Nisancioglu, K. H.: Can we use ice sheet reconstructions to constrain meltwater for deglacial simulations?, Paleoceanography, 27, PA2205, doi:10.1029/2011PA002258, 2012

Boville, B. A. and Gent, P. R.: The NCAR climate system model, version one, J. Climate, 11, 1115-1130, 1998.

Boyle, E. A.: North Atlantic thermohaline circulation during the past 20,000 years linked to high-latitude surface temperature, Nature, 330, 35-40, doi:10.1038/330035a0, 1987.

Boyle, E. and Leach, H.: Last-glacial-maximum North Atlantic deep water: on, off or somewhere in-between? [and discussion], Philos. T. R. Soc. Lon. B, 348, 243-253, 1995.

Briegleb, B. P., Bitz, C. M., Hunke, E. C., Lipscomb, W. H., Holland, M. M., Schramm, J. L., and Moritz, R. E.: Scientific description of the sea ice component in the Community Climate System Model, version three, NCAR Tech, Note NCAR/TN463STR, 70 pp, 2004.

Broecker, W. S.: Salinity history of the northern Atlantic during the last deglaciation, Paleoceanography, 5, 459-467, 1990.

Broecker, W. S.: Paleocean circulation during the last deglaciation: a bipolar seesaw?, Paleoceanography, 13, 119-121, 1998.

Broecker, W. S., Peteet, D. M., and Rind, D.: Does the oceanatmosphere system have more than one stable mode of operation?, Nature, 315, 21-26, 1985.

Bryan, K.: Measurements of meridional heat transport by ocean currents, J. Geophys. Res., 67, 3403-3414, 1962.

Carlson, A. E.: Geochemical constraints on the Laurentide Ice Sheet contribution to meltwater pulse 1A, Quaternary Sci. Rev., 28, 1625-1630, 2009.

Carlson, A. E., Clark, P. U., Raisbeck, G. M., and Brook, E. J.: Rapid Holocene deglaciation of the Labrador sector of the Laurentide Ice Sheet, J. Climate, 20, 5126-5133, 2007.

Carlson, A. E., Ullman, D. J., Anslow, F. S., He, F., Clark, P. U., Liu, Z., and Otto-Bliesner, B. L.: Modeling the surface massbalance response of the Laurentide Ice Sheet to Bølling warming and its contribution to Meltwater Pulse 1A, Earth Planet. Sc. Lett., 315, 24-29, 2012.

Charles, C. D., Lynch-Stieglitz, J., Ninnemann, U. S., and Fairbanks, R. G.: Climate connections between the hemispheres revealed by deep sea sediment core/ice core correlations, Earth Planet. Sci. Lett., 142, 19-27, 1996.

Cheng, W., Bitz, C. M., and Chiang, J. C.: Adjustment of the global climate to an abrupt slowdown of the Atlantic meridional overturning circulation, Geophys. Monogr. Ser., 173, 295-313, 2007.

Clark, P. U. and Mix, A. C.: Ice sheets and sea level of the Last Glacial Maximum, Quaternary Science Reviews, 21, 1-7, 2002.

Clark, P. U., Alley, R. B., Keigwin, L. D., Licciardi, J. M., Johnsen, S. J., and Wang, H.: Origin of the first global meltwater pulse following the last glacial maximum, Paleoceanography, 11, 563-577, 1996.
Clark, P. U., Marshall, S. J., Clarke, G. K., Hostetler, S. W., Licciardi, J. M., and Teller, J. T.: Freshwater forcing of abrupt climate change during the last glaciation, Science, 293, 283-287, 2001.

Clark, P. U., Mitrovica, J., Milne, G., and Tamisiea, M.: Sea-level fingerprinting as a direct test for the source of global meltwater pulse IA, Science, 295, 2438-2441, 2002.

Clauzet, G., Wainer, I., Lazar, A., Brady, E., and Otto-Bliesner, B.: A numerical study of the South Atlantic circulation at the Last Glacial Maximum, Palaeogeogr. Palaeocl., 253, 509-528, 2007.

Collins, W., Rasch, P., Boville, B., Hack, J., McCaa, J., Williamson, D., Briegleb, B., Bitz, C., Shian-Jiann, L., and Minghua, Z.: The Formulation and Atmospheric Simulation of the Community Atmosphere Model Version 3 (CAM3), J. Climate, 19, 2144-2161, 2006.

Curry, W. B. and Oppo, D. W.: Glacial water mass geometry and the distribution of $\delta^{13} \mathrm{C}$ of $\Sigma \mathrm{CO}_{2}$ in the western Atlantic Ocean, Paleoceanography, 20, PA1017, doi:10.1029/2004PA001021, 2005.

Curry, W. B., Marchitto, T. M., McManus, J. F., Oppo, D. W., and Laarkamp, K. L.: Millennial-scale changes in ventilation of the thermocline, intermediate, and deep waters of the glacial North Atlantic, Mechanisms of Global Climate Change at Millennial Time Scales, 59-76, 1999.

Dällenbach, A., Blunier, T., Flückiger, J., Stauffer, B., Chappellaz, J., and Raynaud, D.: Changes in the atmospheric $\mathrm{CH}_{4}$ gradient between Greenland and Antarctica during the Last Glacial and the transition to the Holocene, Geophys. Res. Lett., 27, 10051008, 2000.

Deschamps, P., Durand, N., Bard, E., Hamelin, B., Camoin, G., Thomas, A. L., Henderson, G. M., Okuno, J., and Yokoyama, Y.: Ice-sheet collapse and sea-level rise at the Bolling warming 14600 years ago, Nature, 483, 559-564, 2012.

Duplessy, J., Shackleton, N., Fairbanks, R., Labeyrie, L., Oppo, D., and Kallel, N.: Deepwater source variations during the last climatic cycle and their impact on the global deepwater circulation, Paleoceanography, 3, 343-360, doi:10.1029/PA003i003p00343, 1988.

Fairbanks, R. G.: A 17, 000-year glacio-eustatic sea level record: influence of glacial melting rates on the Younger Dryas event and deep-ocean circulation, Nature, 342, 637-642, 1989.

Flückiger, J., Dällenbach, A., Blunier, T., Stauffer, B., Stocker, T. F., Raynaud, D., and Barnola, J. M.: Variations in atmospheric $\mathrm{N}_{2} \mathrm{O}$ concentration during abrupt climatic changes, Science, 285, 227-230, 1999.

Ganopolski, A. and Rahmstorf, S.: Rapid changes of glacial climate simulated in a coupled climate model, Nature, 409, 153158, 2001.

Gent, P. R., Bryan, F. O., Danabasoglu, G., Lindsay, K., Tsumune, D., Hecht, M. W., and Doney, S. C.: Ocean chlorofluorocarbon and heat uptake during the twentieth century in the CCSM3, J. Climate, 19, 2366-2381, 2006.

Gregoire, L. J., Payne, A. J., and Valdes, P. J.: Deglacial rapid sea level rises caused by ice-sheet saddle collapses, Nature, 487, 219-222, 2012.

He, F.: Simulating transient climate evolution of the last deglaciation with CCSM3, Ph.D. thesis, University of Wisconsin, Madison, WI 53706, 2011.

He, F., Shakun, J. D., Clark, P. U., Carlson, A. E., Liu, Z., OttoBliesner, B. L., and Kutzbach, J. E.: Northern Hemisphere forc- 
ing of Southern Hemisphere climate during the last deglaciation, Nature, 494, 81-85, 2013.

Hughen, K. A., Overpeck, J. T., Lehman, S. J., Kashgarian, M., Southon, J., Peterson, L. C., Alley, R., and Sigman, D. M.: Deglacial changes in ocean circulation from an extended radiocarbon calibration, Nature, 391, 65-68, 1998.

Huybers, P. and Denton, G.: Antarctic temperature at orbital timescales controlled by local summer duration, Nat. Geosci., 1, 787-792, 2008.

Indermühle, A., Monnin, E., Stauffer, B., Stocker, T. F., and Wahlen, M.: Atmospheric $\mathrm{CO}_{2}$ concentration from 60 to $20 \mathrm{kyr} \mathrm{BP}$ from the Taylor Dome ice core, Antarctica, Geophys. Res. Lett., 27, 735-738, 2000.

Joos, F. and Spahni, R.: Rates of change in natural and anthropogenic radiative forcing over the past 20000 years, P. Natl. Acad. Sci. USA, 105, 1425-1430, 2008.

Jouzel, J., Vaikmae, R., Petit, J., Martin, M., Duclos, Y., Stievenard, M., Lorius, C., Toots, M., Melieres, M., Burckle, L., Barkov, N., and Kotlyakov, V.: The two-step shape and timing of the last deglaciation in Antarctica, Clim. Dynam., 11, 151-161, doi:10.1007/BF00223498, 1995.

Kienast, M., Hanebuth, T. J., Pelejero, C., and Steinke, S.: Synchroneity of meltwater pulse 1a and the Bølling warming: new evidence from the South China Sea, Geology, 31, 67-70, 2003.

Licciardi, J. M., Teller, J. T., and Clark, P. U.: Freshwater routing by the Laurentide Ice Sheet during the last deglaciation, in: Mechanisms of Global Climate Change at Millennial Time Scales, 177201, doi:10.1029/GM112p0177, American Geophysical Union, Washington, D. C., 1999.

Lippold, J., Luo, Y., Francois, R., Allen, S. E., Gherardi, J., Pichat, S., Hickey, B., and Schulz, H.: Strength and geometry of the glacial Atlantic Meridional Overturning Circulation, Nat. Geosci., 5, 813-816, doi:10.1038/ngeo1608, 2012.

Liu, Z., Shin, S., Webb, R., Lewis, W., and Otto-Bliesner, B.: Atmospheric $\mathrm{CO}_{2}$ forcing on glacial thermohaline circulation and climate, Geophys. Rett. Lett, 32, L02706, doi:10.1029/2004GL021929, 2005.

Liu, Z., Otto-Bliesner, B., He, F., Brady, E., Tomas, R., Clark, P., Carlson, A., Lynch-Stieglitz, J., Curry, W., Brook, E., Erickson, D., Jacob, R., Kutzbach, J., and Cheng, J.: Transient simulation of last deglaciation with a new mechanism for Bølling-Allerød warming, Science, 325, 310-314, 2009.

Lynch-Stieglitz, J., Curry, W. B., Oppo, D. W., Ninneman, U. S., Charles, C. D., and Munson, J.: Meridional overturning circulation in the South Atlantic at the last glacial maximum, Geochem. Geophys. Geosyst., 7, Q10N03, doi:10.1029/2005GC001226, 2006.

Mackintosh, A., Golledge, N., Domack, E., Dunbar, R., Leventer, A., White, D., Pollard, D., DeConto, R., Fink, D., Zwartz, D., Gore, D., and Lavoie, C.: Retreat of the East Antarctic ice sheet during the last glacial termination, Nature Geoscience, 4, 195202, 2011

Manabe, S. and Stouffer, R. J.: Coupled ocean-atmosphere model response to freshwater input: comparison to Younger Dryas event, Paleoceanography, 12, 321-336, 1997.

Marchitto, T. M. and Broecker, W. S.: Deep water mass geometry in the glacial Atlantic Ocean: a review of constraints from the paleonutrient proxy $\mathrm{Cd} / \mathrm{Ca}$, Geochem. Geophy. Geosy., 7, Q12003, doi:10.1029/2006GC001323, 2006.
Marchitto, T. M., Oppo, D. W., and Curry, W. B.: Paired benthic foraminiferal $\mathrm{Cd} / \mathrm{Ca}$ and $\mathrm{Zn} / \mathrm{Ca}$ evidence for a greatly increased presence of Southern Ocean Water in the glacial North Atlantic, Paleoceanography, 17, 10-1, doi:10.1029/2000PA000598, 2002.

McManus, J., Francois, R., Gherardi, J.-M., Keigwin, L., and Brown-Leger, S.: Collapse and rapid resumption of Atlantic meridional circulation linked to deglacial climate changes, Nature, 428, 834-837, 2004.

Menviel, L., Timmermann, A., Elison Timm, O., and Mouchet, A.: Deconstructing the Last Glacial termination: the role of millennial and orbital-scale forcings, Quat. Sci. Rev., 30, 1155-1172, 2011.

Menviel, L., England, M. H., Meissner, K. J., Mouchet, A., and Yu, J.: Atlantic-Pacific seesaw and its role in outgassing $\mathrm{CO}_{2}$ during Heinrich events, Paleoceanography, 29, 58-70, 2014.

Mikolajewicz, U.: Effect of meltwater input from the Antarctic ice sheet on the thermohaline circulation, Ann. Glaciol., 27, 311315, 1998.

Monnin, E., Indermühle, A., Dällenbach, A., Flückiger, J., Stauffer, B., Stocker, T. F., Raynaud, D., and Barnola, J. M.: Atmospheric $\mathrm{CO}_{2}$ concentrations over the last glacial termination, Science, 291, 112-114, 2001.

Negre, C., Zahn, R., Thomas, A. L., Masqué, P., Henderson, G. M., Martínez-Méndez, G., Hall, I. R., and Mas, J. L.: Reversed flow of Atlantic deep water during the Last Glacial Maximum, Nature, 468, 84-88, 2010.

Otto-Bliesner, B. L., Brady, E. C., Clauzet, G., Tomas, R., Levis, S., and Kothavala, Z.: Last glacial maximum and Holocene climate in CCSM3, J. Climate, 19, 2526-2544, 2006.

Peltier, W. R.: Ice age paleotopography, Science, 265, 195-195, 1994.

Peltier, W.: Global glacial isostasy and the surface of the ice-age Earth: the ICE-5G (VM2) model and GRACE, Annu. Rev. Earth Planet. Sci., 32, 111-149, doi:10.1146/annurev.earth.32.082503.144359, 2004.

Peltier, W.: On the hemispheric origins of meltwater pulse 1a, Quaternary Sci. Rev., 24, 1655-1671, 2005.

Peltier, W. and Fairbanks, R. G.: Global glacial ice volume and Last Glacial Maximum duration from an extended Barbados sea level record, Quaternary Sci. Rev., 25, 3322-3337, 2006.

Piotrowski, A. M., Goldstein, S. L., Hemming, S. R., and Fairbanks, R. G.: Temporal relationships of carbon cycling and ocean circulation at glacial boundaries, Science, 307, 1933-1938, 2005.

Praetorius, S. K., McManus, J. F., Oppo, D. W., and Curry, W. B.: Episodic reductions in bottom-water currents since the last ice age, Nat. Geosci., 1, 449-452, 2008.

Rind, D., Demenocal, P., Russell, G. L., Sheth, S., Collins, D., Schmidt, G. A., and Teller, J.: Effects of glacial meltwater in the GISS Coupled Atmosphere-Ocean Model: Part I: North Atlantic Deep Water response, J. Geophys. Res., 106, 27355-27365, 2001.

Roberts, N. L., Piotrowski, A. M., McManus, J. F., and Keigwin, L. D.: Synchronous deglacial overturning and water mass source changes, Science, 327, 75-78, 2010.

Schneider von Deimling, T., Ganopolski, A., Held, H., and Rahmstorf, S.: How cold was the last glacial maximum?, Geophys. Res. Lett., 33, L14709, doi:10.1029/2006GL026484, 2006. 
Seidov, D. and Maslin, M.: Atlantic ocean heat piracy and the bipolar climate see-saw during Heinrich and Dansgaard-Oeschger events, J. Quat. Sci., 16, 321-328, 2001.

Seidov, D., Barron, E., and Haupt, B. J.: Meltwater and the global ocean conveyor: northern versus southern connections, Global Planet. Change, 30, 257-270, 2001.

Shin, S.-I., Liu, Z., Otto-Bliesner, B., Brady, E., Kutzbach, J., and Harrison, S.: A simulation of the Last Glacial Maximum climate using the NCAR-CCSM, Clim. Dynam., 20, 127-151, doi:10.1007/s00382-002-0260-x, 2003.

Stanford, D., Rohling, E. J., Bacon, S., Roberts, A. P., Grousset, F. E., and Bolshaw, M.: A new concept for the paleoceanographic evolution of Heinrich event 1 in the North Atlantic, Quat. Sci. Rev., 30, 1047-1066, 2011.

Stanford, J. D., Rohling, E. J., Hunter, S. E., Roberts, A. P., Rasmussen, S. O., Bard, E., McManus, J., and Fairbanks, R. G.: Timing of meltwater pulse 1a and climate responses to meltwater injections, Paleoceanography, 21, PA4103, doi:10.1029/2006PA001340, 2006.

Stenni, B., Masson-Delmotte, V., Selmo, E., Oerter, H., Meyer, H., Röthlisberger, R., Jouzel, J., Cattani, O., Falourd, S., Fischer, H., Hoffmann, G., Iacumin, P., Johnsen, S., Minster, B., and Udisti, R.: The deuterium excess records of EPICA Dome C and Dronning Maud Land ice cores (East Antarctica), Quaternary Sci. Rev., 29, 146-159, 2010.

Stommel, H.: Thermohaline convection with two stable regimes of flow, Tellus, 13, 224-230, 1961.
Stott, L., Timmermann, A., and Thunell, R.: Southern hemisphere and deep-sea warming led deglacial atmospheric $\mathrm{CO}_{2}$ rise and tropical warming, Science, 318, 435-438, 2007.

Timmermann, A., Timm, O., Stott, L., and Menviel, L.: The Roles of $\mathrm{CO}_{2}$ and Orbital Forcing in Driving Southern Hemispheric Temperature Variations during the Last 21000 Yr, J. Climate, 22, 1626-1640, 2009.

Wainer, I., Goes, M., Murphy, L. N., and Brady, E.: Changes in the intermediate water Mass Formation Rates in the Global Ocean for the Last Glacial Maximum, Mid-Holocene and Pre-Industrial Climates, Paleoceanography, 27, PA3101, doi:10.1029/2012PA002290, 2012.

Weaver, A. J., Saenko, O. A., Clark, P. U., and Mitrovica, J. X.: Meltwater pulse 1A from Antarctica as a trigger of the BøllingAllerød warm interval, Science, 299, 1709-1713, 2003.

Yu, E.-F., Francois, R., and Bacon, M. P.: Similar rates of modern and last-glacial ocean thermohaline circulation inferred, Nature, 379, 689-694, doi:10.1038/379689a0, 1996.

Zahn, R., Schönfeld, J., Kudrass, H. R., Park, M. H., Erlenkeuser, H., and Grootes, P.: Thermohaline instability in the North Atlantic during meltwater events: Stable isotope and ice-rafted detritus records from Core SO75-26KL, Portuguese Margin, Paleoceanography, 12, 696-710, 1997.

Zhang, X., Lohmann, G., Knorr, G., and Xu, X.: Different ocean states and transient characteristics in Last Glacial Maximum simulations and implications for deglaciation, Clim. Past, 9, 23192333, doi:10.5194/cp-9-2319-2013, 2013. 